\title{
Fischer Assays of Oil Shale Drill Cores and Rotary Cuttings from the Piceance Basin, Colorado-2009 Update
}

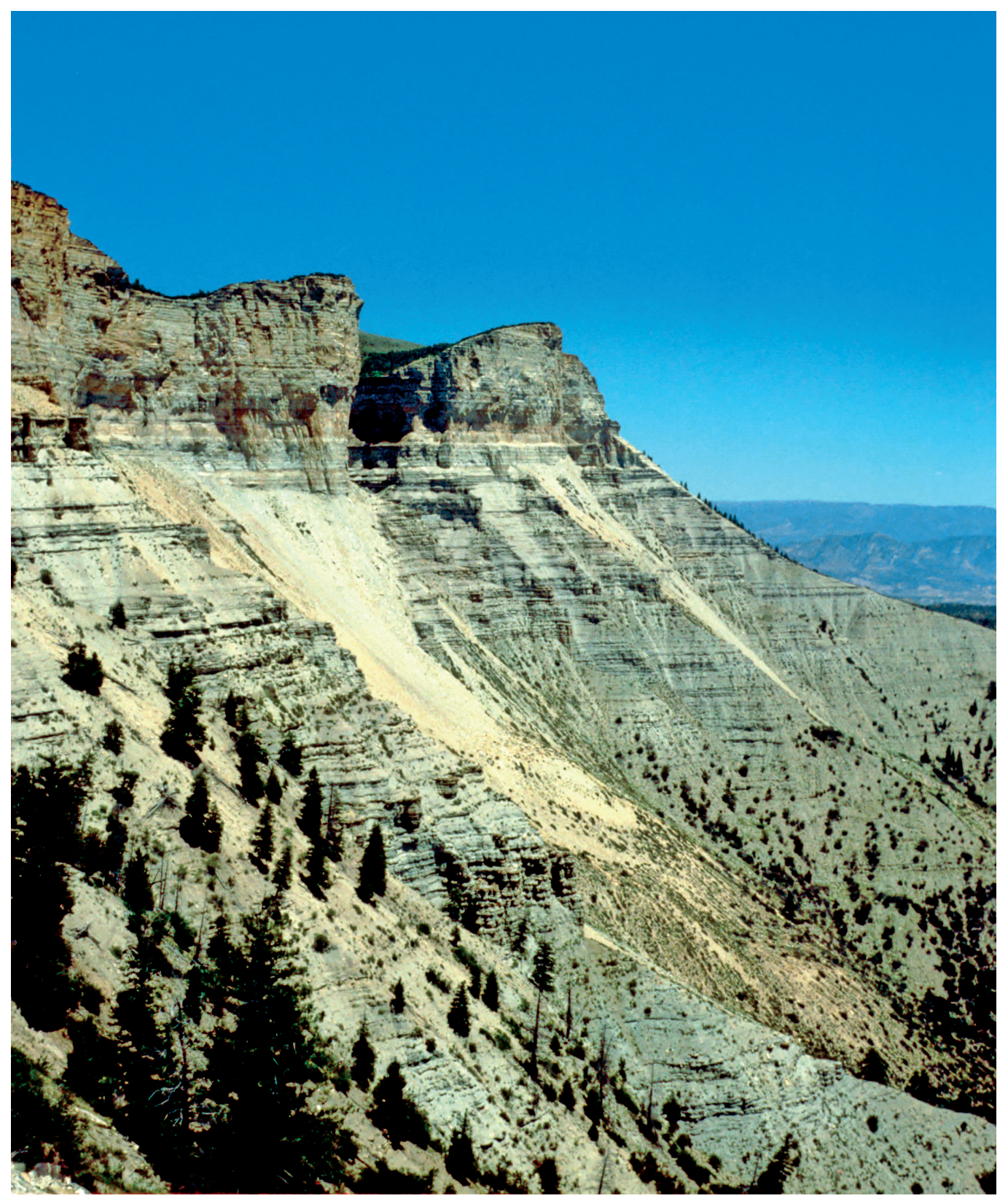

Open-File Report 98-483 Version 2.0 


\title{
U.S. Department of the Interior
}

\author{
KEN SALAZAR, Secretary
}

\section{U.S. Geological Survey \\ Suzette M. Kimball, Acting Director}

U.S. Geological Survey, Reston, Virginia 2009

For product and ordering information:

World Wide Web: http://www.usgs.gov/pubprod

Telephone: 1-888-ASK-USGS

For more information on the USGS - the Federal source for science about the Earth, its natural and living resources, natural hazards, and the environment:

World Wide Web: http://www.usgs.gov

Telephone: 1-888-ASK-USG S

Suggested citation:

U.S. G eological Survey 0 il Shale Assessment Team, 2009, Fischer assays of oil-shale drill cores and rotary cuttings from the Piceance Basin, Colorado-2009 Update: U.S. G eological Survey 0 pen-File Report 98-483 Version 2.0, $16 \mathrm{p}$.

Any use of trade, product, or firm names is for descriptive purposes only and does not imply endorsement by the U.S. Government.

Although this report is in the public domain, permission must be secured from the individual copyright owners to reproduce any copyrighted material contained with in this report.

Cover photograph: Anvil Point, $\mathrm{P}$ iceance Basin, northwestern Colorado 


\section{Contents}

Introduction 2009 Update

2009 CD-ROM

Readme File for the U.S. Geological Survey Open-File Report 98-483

\section{Figure}

1. Map showing the distribution of the Mesaverde Formation (or Group) and the

Wasatch, Green River, and Uinta Formations, and locations of oil shale boreholes in the Piceance Basin, northwestern Colorado.

\section{Table}

1. Names and definitions for the column headers in the Fischer assay data spreadsheet and database. 


\section{Fischer Assays of Oil Shale Drill Cores and Rotary Cuttings from the Piceance Basin, Colorado-2009 Update}

By Tracey J. Mercier, Michael E. Brownfield, Ronald C. Johnson, and Jesse G. Self

\section{INTRODUCTION-2009 UPDATE}

The U.S. Geological Survey (USGS) recently completed a comprehensive assessment of in-place oil (Johnson and others, 2009), regardless of richness, in oil shales of the Eocene Green River Formation of the Piceance Basin of western Colorado (fig. 1). This 2009 assessment is based on the considerable amount of data that has been collected since the previous USGS in-place assessment was published in 1989. Much of the new data that were previously company confidential were since donated by industry after interest in developing oil shale decreased in the 1980s.

As a part of this assessment, a new Fischer assay data set was created containing considerably more oil-yield data points than the previous assessment. This new database incorporates the Fischer assay data from Dyni (1998), which contained 737 sets of borehole assay data or about 298,500 records from boreholes drilled in the Piceance Basin. After checking and correcting the data for location, elevation, and input errors, the assessment team removed two files (boreholes C0300 and C0363A) from Dyni’s legacy assay data. This column-delimited data were then combined into a new Microsoft Access (Microsoft Corporation, 2006) database and the assessment team added Fischer assay data for 47 new boreholes (782 boreholes), increasing the number of records to 321,389 . This CD-ROM is an update of the legacy data published by Dyni (1998). 


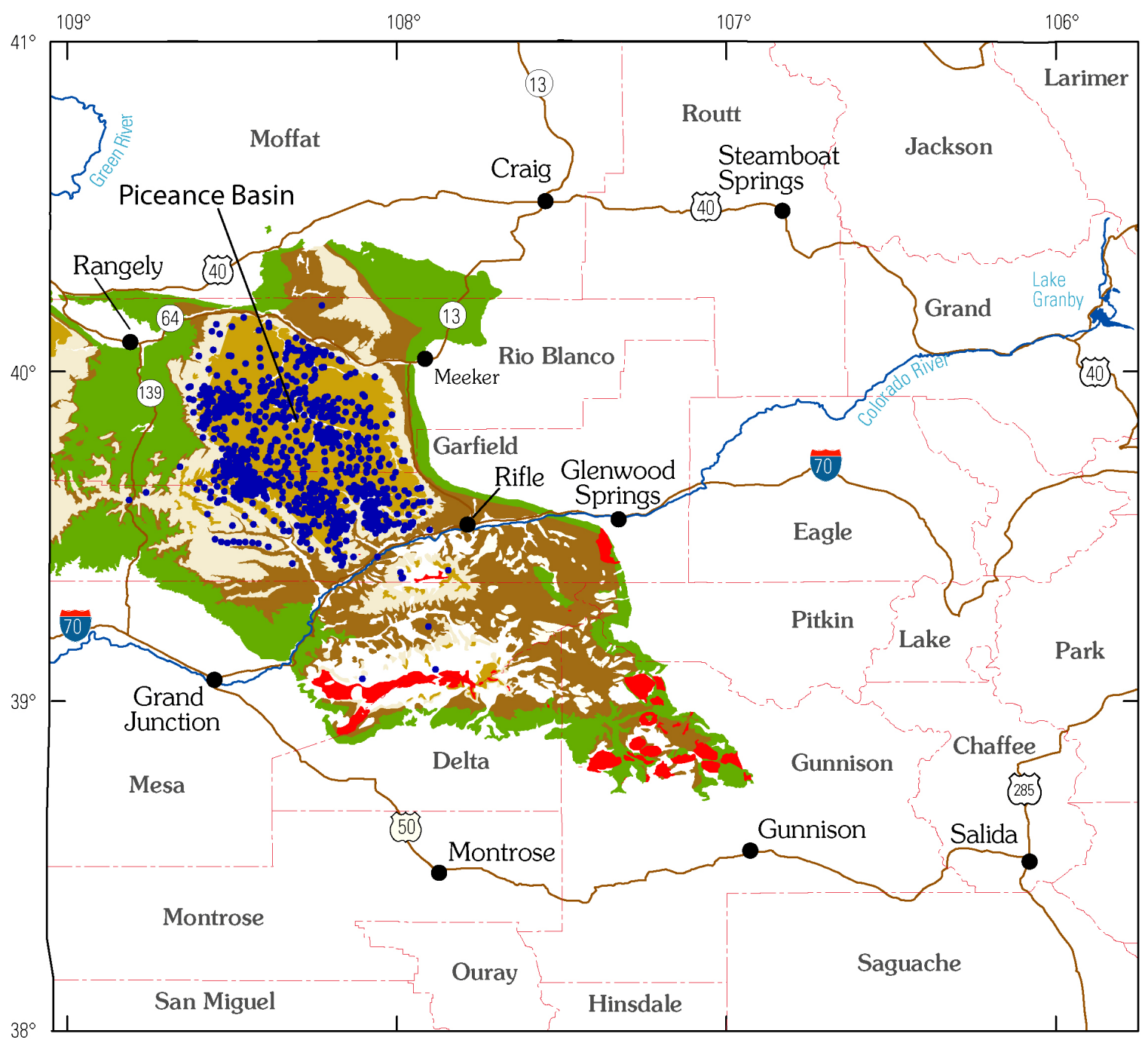

\section{EXPLANATION}

\begin{tabular}{|l|}
\hline \multicolumn{1}{|c|}{$\begin{array}{c}\text { Undivided Quaternary, Tertiary, } \\
\text { Mesozoic, and Paleozoic }\end{array}$} \\
Tertiary \\
\begin{tabular}{|l|}
\hline Uinta Formation and undivided \\
Tertiary
\end{tabular} \\
\begin{tabular}{|l} 
Green River Formation \\
Wasatch Formation and undivided \\
lower Tertiary
\end{tabular} \\
Cretaceous $\quad \begin{array}{c}\text { Mesaverde Fm. and Mesaverde } \\
\text { Group coal-bearing rocks }\end{array}$
\end{tabular}

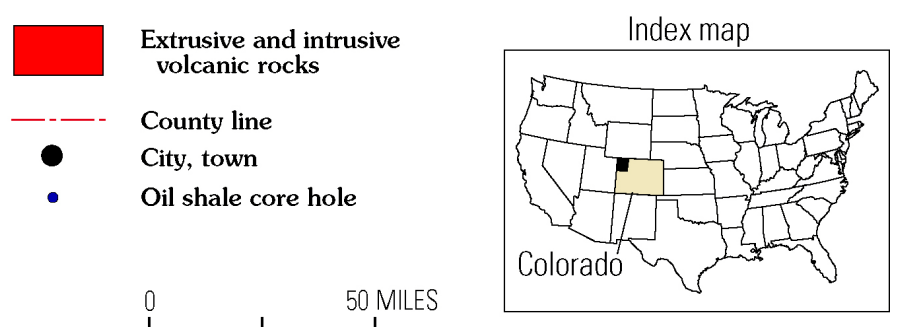

Figure 1. Map showing the distribution of the Mesaverde Formation (or Group) and the Wasatch, Green River, and Uinta Formations and locations of oil shale boreholes in the Piceance Basin, northwestern Colorado. Modified from Brownfield and others (2000). 


\section{CD-ROM}

The Fischer assay data included in this CD-ROM (in the Spreadsheets folder) is presented in both comma-separated values (Colorado Oil Shale Assays.csv) and Access 2003 (Colorado Oil Shale Database.mdb) formats. In a few cases, there are two sets of assay data listed for the same drill hole, and the borehole number in the spreadsheet is followed by an " $\mathrm{A}$ " or " $\mathrm{B}$ ". The USGS drill hole number is followed by a corresponding suffix. Rotary-drilled holes are identified by the suffix "R" following the USGS drill hole number, whereas core holes have no suffix after the drill hole number. The suffix " $\mathrm{S}$ " identifies Fischer assays from samples collected from surface sections. Boreholes for which the assessment team could not locate the legacy data are identified by the suffix "U". Surface measured sections used for control points are identified by the suffix " $X$ ". Data fields included in the Fischer assay data spreadsheet are defined in table 1. The legacy data (Dyni, 1998) are contained in this CD-ROM (Dyni_1998 folder) or at the following URL: http://energy.cr.usgs.gov/other/oil_shale/. The original Fischer assay text files and the added Fischer assay text files for the 45 new boreholes are included with the legacy data.

Data on core and rotary boreholes as well as a few surface sections, originally compiled by J.R. Dyni (written commun., 2007), are included in a Microsoft Excel (Microsoft Corporation, 2006) location file. In addition to well locations, the file contains operator and well name, elevation, core location when known, depths of lithologic log units, geophysical logs, and additional data. Any errors and deletions were corrected, and new boreholes and surface sections were added. Information for 1,042 core and rotary holes, oil and gas tests, and a few surface sections of oil shale are contained in the 
Colorado Boreholes and Tops.xls spreadsheet, which is also provided as an ASCII text file (OFR-98-483-v02 Spreadsheets folder. Also included in this update is a data dictionary for the location spreadsheet in both Microsoft Word (Microsoft Corporation, 2006) and text document formats (OFR-98-483-v02\Spreadsheets \Data Dictionaries folder).

Modified to reflect the oil shale assessment team's new correlation scheme of the 17 oil shale zones assessed in the Piceance Basin, a second unpublished file containing tops information is included in this update. This file was appended to include the new boreholes (OFR-98-483-v02 \Spreadsheets folder; Colorado Boreholes and Tops.xls) and combined with the corrected Excel location file. This file contains data on all 1,042 boreholes and surface sections. A data dictionary for the tops file (Colorado Boreholes and Tops Fieldname Descriptions file, OFR-98-483-v02\Spreadsheets \Data Dictionaries folder) is included in this update in both Microsoft Word (Microsoft Corporation, 2006) and text document formats.

For this update of the Piceance Basin Fischer assay data, geospatial data and associated metadata are also included (OFR-98-483-v02/Spatial and Metadata folders) for 1,011 boreholes and surface sections. The majority of the locations were digitized in ESRI ArcGIS v. 9.2 (Environmental Systems Research Institute [ESRI], 2006) based on footage measurements north, south, east, and west of PLSS section corners contained in the original database. A custom tool was used that combined the distance and sketch tools in ArcEditor to measure and plot points. Source PLSS files were obtained from the Bureau of Land Management and projected to North American Datum 27 (NAD27). Where footage measurements were unavailable, the location was digitized in the center of 
the 1/4-1/4 section, $1 / 4$ section, or the center of the section. In short, the best data location available in the original database was used. Spatial data file can be joined or related to the boreholes and assays tables by using the "USGSID" column. One-to-many relationships between the boreholes and assays tables can be viewed in the Access form "Colorado Boreholes and Tops form."

Extensive quality control was performed by the assessment team to publish this Piceance Basin Fischer assay data update. If, however, any errors or omissions of data are found in this disc, users are encouraged to contact Ronald C. Johnson at rcjohnson@usgs.gov, Michael E. Brownfield atmbrownfield@usgs.gov,or Tracey J. Mercier attmercier@usgs.gov. 
Table 1. Names and definitions of the column headers (fields) in the Fischer assay data spreadsheet and database.

\begin{tabular}{ll}
\hline Column name & \multicolumn{1}{c}{ Column definition } \\
\hline USGSID & $\begin{array}{c}\text { Unique drill hole number assigned by the U.S. } \\
\text { Geological Survey } \\
\text { TOPFT }\end{array}$ \\
$\begin{array}{c}\text { Depth, in feet, measured from surface datum to top of } \\
\text { sampled interval } \\
\text { Depth, in feet, measured from surface datum to base of } \\
\text { sampled interval }\end{array}$ \\
BHTFT & Amount of shale oil in weight percent \\
WATERPCT & Amount of water in weight percent \\
SHLRSDPCT & Amount of shale residue in weight percent \\
GASPLSLSPCT & Amount of "gas plus loss" in weight percent \\
OILGPT & Shale oil in U.S. gallons per short ton of rock \\
WATERGPT & Water in U.S. gallons per short ton of rock \\
SPCFGRAV & Specific gravity of shale oil \\
COKETEND & Tendency for spent shale to coke \\
\hline
\end{tabular}

\section{References}

Brownfield, M.E., Hettinger, R.D., and Johnson, E.A., 2000, A summary of the stratigraphy, coal resources, and coal-bed methane potential of northwest Colorado, in Kirschbaum, M.A., Roberts, L.N.R., and Biewick, L.R.H., eds., Geologic assessment of coal in the Colorado Plateau - Arizona, Colorado, New Mexico, and Utah: U.S. Geological Survey Professional Paper 1625-B, chap. I, two CD-ROMs, $25 \mathrm{p}$.

Dyni, J.R., 1998, Fischer assays of oil-shale drill cores and rotary cuttings from the Piceance Creek Basin, Colorado: U.S. Geological Survey Open-File Report 98-483, CD-ROM. 
Environmental Systems Research Institute (ESRI), 2006, ArcGIS, version 9.2: ESRI, Redlands, Calif., http://www.esri.com/software/arcgis/index.html (last accessed August 20, 2009).

Johnson, R.C., Mercier, T.J., Brownfield, M.E., Pantea, M.P., and Self, J.G., 2009, Assessment of in-place oil shale resources of the Green River Formation, Piceance Basin, western Colorado: U.S. Geological Survey Fact Sheet 2009-3012, 6 p. Microsoft Corporation, 2006, Microsoft Access, Excel, \& Word (part of Microsoft Office 2007). 
John R. Dyni's original readme document for the U.S. Geological Survey Open-

File Report

U.S. Department of the Interior

U.S. Geological Survey

Fischer assays of oil-shale drill cores and rotary cuttings from the Piceance Creek Basin, Colorado

by

John R. Dyni

U.S. Geological Survey

Denver, Colorado

Open-File Report 98-483

Prepared in cooperation with the U.S. Department of Energy

This report is preliminary and has not been reviewed for conformity with U.S.

Geological Survey editorial standards (or with the North American Stratigraphic Code). Any use of trade, product, or firm names is for descriptive purposes only and does not imply endorsement by the U.S. Government. 


\begin{abstract}
This CD-ROM includes Fischer assays of samples of drill cores and cuttings from bore holes drilled in the Eocene Green River oil-shale deposits in western Colorado. The size of this database is 22.8 megabytes and contains about 298,500 records divided into 737 sets of assays. Each data set represents analyses from one borehole. The data are in ASCII format in column-delimited fields for use on a PC computer. Intervals that were not assayed owing to missing samples are included in the database and are identified by depth and a series of " $0.0 \mathrm{~B}$ "s that fill each field. The data include Fischer assays made by the former U.S. Bureau of Mines (USBM) oil-shale laboratory in Laramie, Wyoming, but also include many analyses made by private laboratories which were donated to the U.S. Geological Survey (USGS).
\end{abstract}

These assays are part of a larger collection of subsurface information including geophysical and lithologic logs, water data, chemical and X-ray diffraction analyses on the Green River oil-shale deposits in Colorado, Wyoming, and Utah held by the USGS. Because of current interest by industry, this CD-ROM disc containing Fischer assay data for the Green River oil-shale deposits in western Colorado is being released to the public. Company-confidential assays are not included.

\title{
INTRODUCTION
}

For many years, the USGS has collected drill cores and subsurface data from bore holes drilled in the Eocene Green River oil-shale deposits in the three-state area of Colorado, Wyoming, and Utah. Some data and drill cores were also collected from the Devonian oil-shale deposits in eastern United States as well as from a few foreign deposits. The purpose of collecting these drill cores and data was to preserve them for use by researchers and for the time when Green River oil-shale deposits becomes economic as an alternate source of fossil energy.

The types of data include thousands of Fischer (shale-oil) assays of drill cores and cuttings from rotary-drilled holes; geophysical and lithologic logs of drill holes; chemical, water-quality and X-ray diffraction analyses; rock mechanics data; and other types of information. Although this collection of data is far from complete, it probably represents the largest single source of subsurface information on the Green River oilshale deposits in the three-state area.

Most of the Fischer assays were obtained from the former USBM laboratory in Laramie, Wyoming. From the late 1940s to the early 1980s, this agency analyzed many cores and cuttings from holes drilled by Federal agencies and by industry in the Green River deposits in the three-state area. A large amount of data for exploratory holes drilled in the Green River Formation was also obtained from energy companies that hold private or leased oil-shale lands in the region. Many of these companies generously donated much analytical data as well as drill cores that are being preserved by the USGS.

During the 1970's and 1980's, the USBM and the USGS each prepared digital databases of the Fischer assays of the Green River oil-shale deposits. The USBM database 
included all of the assays made at its Laramie laboratory from the 1940's to the early 1980 's, plus some analyses of drill cores furnished by several private companies. These data were made available to the public through the National Technical Information Service (NTIS) (Laramie Energy Technology Center, 1984). The USGS also prepared a digital database that included the USBM assays, but also included many analyses from numerous core holes drilled by private companies that were not available to the USBM. These analyses were also made available to the public on magnetic tapes through the NTIS (Pitman, 1982, and Pitman and Van Trump, 1974, 1975). However, recent inquiries found that some of these tapes containing Fischer assays have degraded in storage and are no longer readable.

In the early 1990's the U.S. Department of Energy (DOE) and the USGS initiated a project to create a digital National Oil Shale Database (NOSDB) that would combine all available Fischer assay data in the possession of the USBM and the USGS. Assay data on private lands that were not in USGS files were also obtained from private companies and these were added to the database.

The DOE provided two years of funding for clerical help to digitize the Fischer assay analyses. Most of this work was accomplished at the local office of the DOE in Laramie, Wyoming, under the direction of the author. The original data sheets were scanned and saved as PCX image files. These image files are not included on this disc.

The data are not complete with respect to bore hole location, especially for wells which were rotary-drilled. However, most of these wells are oil and gas tests, and their locations can be obtained from commercial service companies.

\section{FISCHER ASSAYS}

A total of 737 sets of Fischer assay data for Colorado - mostly for bore holes drilled in the Piceance Creek Basin - are included on this CD-ROM. The total size of the database is 22.8 megabytes containing about 298,500 records. The data are in ASCII format in column-delimited fields. Each file contains assay data for a single bore hole. Each bore hole was assigned a unique 4-digit number preceded by "C" for Colorado. In a few instances, two sets of assays from the same bore hole are indicated by an "A" or "B" following the bore hole number. Rotary-drilled holes are identified by the suffix " $R$ " following the well number. Fischer assays on samples collected from several surface sections have an "S" appended to the file number.

The first two records in each file contain information about the drill hole as follows:

\section{Record 1}

Columns 1 to 46: name of the company and the drill hole name.

Columns 47 to 64 : well location by township, range, and section.

Record 2

Columns 1-10: well location within the section measured in feet from the west or east boundaries of the section (i.e., FEL or FWL). 
Columns 11-20: well location measured in feet from the south or north boundaries of the section (i.e., FNL or FSL).

Columns 21-32: well location in degrees latitude to six decimal places.

Columns 33-45: well location in degrees longitude to six decimal places.

Columns 46-50: elevation of the well in feet above sea level.

Columns 51-52: elevation datum indicated by one or two characters as follows: $\mathrm{DC}=$ top of drill collar, $\mathrm{G}=$ ground elevation, $\mathrm{RB}=$ top of rotary bushing).

The first Fischer assay begins with record 3 and continues to the last record in the file. The format is similar to that used by the USBM.

Beginning with record 3, the assay data are ordered by columns as follows:

Columns 1-11: Six-digit USBM Laramie laboratory number, left justified. The first two digits of the laboratory number indicate the year the analysis was made and the remaining four digits indicate the order in which the analysis was made in that year. These laboratory numbers are included in the database because the unused portions of the samples analyzed by the USBM are preserved by the USGS and are identified by these numbers. Laboratory numbers of samples analyzed by private laboratories are not included in this database because the USGS did not retain the unused portions of these samples.

Columns 12-21: Depth, in feet, measured from the surface datum to the top of the sampled interval.

Columns 22-29: Depth, in feet, measured from the surface datum to the base of the sampled interval.

Columns 30-35: Amount of shale oil in weight percent.

Columns 36-41: Amount of water in weight percent.

Columns 42-47: Amount of shale residue in weight percent.

Columns 48-54: Amount of "gas plus loss" in weight percent.

Columns 55-60 Shale oil in U.S. gallons per short ton of rock.

Columns 61-66: Water in U.S. gallons per short ton of rock.

Columns 67-72: Specific gravity of the shale oil.

Columns 73-76: Tendency for spent shale to coke.

Missing data are indicated by “0.0B", or " $0.000 \mathrm{~B}$ ” for a missing specific gravity value. Missing sequences of drill core are not distinguished as such, but are included in a sequence with a top and bottom depth followed by $0.0 \mathrm{Bs}$ in all of the data fields, as well as a missing laboratory number if the sample was analyzed by the USBM. Therefore, the depths recorded in each data set are continuous from the top of the assayed sequence to the bottom of the sequence and include missing sequences of drill core. Most of the 298,500 records in this database are Fischer assays but do include records of missing samples or intervals.

It should be kept in mind that results of the Fischer assays made by different laboratories may not be strictly comparable because of differences in the method of analysis. Although most laboratories followed the ASTM modified Fischer assay method (American Society for Testing and Materials, 1980), there were some differences found 
between several laboratories. One laboratory was noted to yield consistently higher results, owing in part to using a more finely ground sample. Another laboratory gave consistently higher than expected results, but the reason is unclear. However, most Fischer assays made by the USBM should give consistent values between bore holes. Fischer assays of cuttings from rotary holes should be used with caution because the cuttings tend to mix and blend with each other on their recovery from the bore hole. They are not recommended for resource evaluations.

Although useful for resource evaluation and stratigraphic studies of oil-shale deposits, the Fischer assay does not give a complete picture of the energy available in the organic fraction of the oil shale. The method does not measure the composition of the gases released, but merely subtracts the sum of the weights of oil, water, and spent shale from 100 percent, and reports this amount as "gas plus loss". Gas plus loss includes all noncondensable gases released in the Fischer assay including light hydrocarbons and carbon dioxide, plus analytical errors.

In the Piceance Creek Basin, the carbonate minerals dawsonite $\left[\mathrm{NaAl}(\mathrm{OH})_{2} \mathrm{CO}_{3}\right]$ nahcolite $\left(\mathrm{NaHCO}_{3}\right)$ are abundant in oil shale in the central part of the basin. These sodium carbonates decompose at retorting temperatures giving anomalously high amounts of "gas plus loss" (i.e., carbon dioxide) and water for samples of oil shale containing these minerals. The high values of water and "gas plus loss" can be used to estimate the percentages of nahcolite and dawsonite in the sample (Beard, Tait, and Smith, 1974).

If errors or omissions in this database are found, users of this disc are encouraged to contact the author at jdyni@crgdmail1.cr.usgs.gov.

\section{References}

American Society for Testing and Materials, 1980, Standard method of test for oil from oil shale: Annual Book of ASTM Standards, Part 25, Designation D 3904-80, p. 513515.

Beard, T.N., Tait, D.B., and Smith, J.W., 1974, Nahcolite and dawsonite resources in the Piceance Creek basin, Colorado, in Guidebook to the energy resources of the Piceance Creek basin, Colorado, Rocky Mountain Association of Geologists, 25th Annual Field Conference: p. 101-109.

Laramie Energy Technology Center, 1984, Fischer assay oil-shale data (June 1940-June 1983): National Technical Information Service [magnetic tape] PB-110881/XDD.

Pitman, J.K., 1982, Oil-shale Fischer assay analysis from selected coreholes in the Piceance Basin, Colorado: National Technical Information Service [magnetic tape] PB82-134875/XDD. 
Pitman, J.K., and Van Trump, George, 1974, Oil shale Fischer assay data for coreholes in the Piceance Creek Basin, Colorado: National Technical Information Service [magnetic tape] PB-230 607/4/XDD.

Pitman, J.K., and Van Trump, George, 1975, Magnetic tape containing oil-shale Fischer assay data for coreholes in the Uinta Basin, Utah: National Technical Information Service [magnetic tape] PB-238 682/9/XDD. 